\title{
Salted lamb meat blanket of Petrolina-Pernambuco, Brazil: Process and quality
}

\author{
Nely de Almeida PEDROSA ${ }^{1 *}$, Marta Suely MADRUGA², Roberto Germano COSTA³, \\ Geovergue Rodrigues MEDEIROS ${ }^{4}$, Terezinha Fernandes DUARTE5, \\ Tadeu Vinhas VOLTOLINI ${ }^{6}$, Silvana Souza MARTINS ${ }^{7}$
}

\begin{abstract}
Salted lamb meat blanket, originated from boning, salting, and drying of whole lamb carcass, was studied aiming at obtaining information that support the search for guarantees of origin for this typical regional product from the city of PetrolinaPernambuco-Brazil. Data from three processing units were obtained, where it was observed the use of a traditional local technology that uses salting, an ancient preservation method; however, with a peculiar boning technique, resulting in a meat product with great potential for exploitation in the form of meat blanket. Based on the values of $\mathrm{pH}(6.22 \pm 0.22)$, water activity $(0.97 \pm 0.02)$, and moisture $(69.86 \pm 2.26)$ lamb meat blanket is considered a perishable product, and consequently it requires the use of other preservation methods combined with salt, which along with the results of the microbiological analyses (absence of Salmonella sp, score $<10 \mathrm{MPN} / \mathrm{g}$ of halophilic bacteria, total coliforms between $6.7 \times 10^{3}$ and $5.2 \times 10^{6} \mathrm{FUC} / \mathrm{g}$, and Staphylococcus from $8.1 \times 10^{3} \mathrm{CFU} / \mathrm{g}$ at uncountable) reinforce the need of hygienic practices to ensure product safety. These results, together with the product notoriety and the organization of the sector are important factors in achieving Geographical Indication of the Salted lamb Meat blanket of Petrolina.
\end{abstract}

Keywords: good practices; geographical indication; microbiology.

\section{Introduction}

Salted and dried meats are widely consumed in Brazil as a source of animal protein. Among which, sun-dried meat, jerked beef, and more specifically salted lamb meat blanket stand out as typical regional product with significant acceptance in the lower basin of the São Francisco River Valley.

Unlike other Brazilian regions, in which the salting process is performed in meat cuts (topside, ribs, shoulder, ham, loin, etc.), in the Lower Basin of the São Francisco River Valley, especially the city of Petrolina - PE, whole goat and lamb carcass are boned, and the muscles are transformed into a sun-dried blanket to facilitate the drying process, with a more homogeneous salt distribution and full use of the carcass as deboned meat. Due to the fact that the whole carcass is boned and the muscles are stretched out into a thin blanket, the product looks like a fabric sheet or a blanket, and the names "goat blanket" or "lamb blanket" are also used according to the animal species. In the region evaluated, the process used to obtain the salted meat blanket has been the same for decades, i.e., it has been passed down from generation to generation (Costa et al., 2010, 2011).

Salted lamb meat blanket is a product traditionally sold in street markets and butcher shops for domestic consumption and to restaurants in the Lower Basin of the São Francisco River Valley, for example, the restaurants belonging to the gastronomic complex called "Bodódromo" in Petrolina-PE. This is the largest complex in Latin America to serve dishes prepared with goat and lamb meat, mainly called "Roast Goat" (Roast Lamb), and it is currently one of the major tourism attractions in the city of Petrolina receiving thousands of visitors every year (Costa et al., 2010).

According to Bressan, in the preface to the technical manual for the elaboration of salted lamb blanket (Costa et al., 2010), the wide acceptance of this product plays an important role in the national context since it is a heritage of expertise involving soil, plants, and animals as well as associated rural populations, thus making an important contribution to the conservation of local biological resources. This "production chain" or "heritage" linked to "Lamb Meat Blanket of Petrolina" deserves industrial/intellectual property protection, possibly including a certification mark of Indication of Provenance or Designation of Origin.

Designation of origin and indication of provenance are tools to add value and consist of basic requirements for the recognition and protection of regional/typical products and systems associated with them. Salting lamb and goat meat is a reality; some traditional salted products, such as sun-dried beef, jerked beef (Brazil), bresaola salted beef (Italy), and Cecinas (Spain), made with goat and lamb meat, are part of the daily diet

\footnotetext{
Received 15 May, 2013

Accepted 10 Jan., 2014 (006095)

Department of Food Technology - DTA/CTDR, Federal University of Paraíba - UFPB, João Pessoa, PB, Brazil, e-mail: nelypedrosa@ig.com.br

2 Post-graduation in Food Science and Technology - PPGCTA/CT, Federal University of Paraíba -UFPB, João Pessoa, PB, Brazil

3 Department of Agricultural, Federal University of Paraíba - UFPB, Bananeiras, PB, Brazil

${ }^{4}$ National Institute of the Semi-Arid Region - INSA, Campina Grande, PB, Brazil

${ }^{5}$ Embrapa Caprinos e Ovinos, Sobral, CE, Brazil

${ }^{6}$ Embrapa Semiárido - CPATSA, Petrolina, PE, Brazil

SENAI Technical School at Petrolina, Petrolina, PE, Brazil

${ }^{*}$ Corresponding author
} 
of consumers and have the potential for recording provenance of meat (Madruga \& Bressan, 2011).

There are several studies worldwide on products submitted to salting and drying processes. Hierro et al. (2003), in a study on the Spanish product "cecina", mentions similar products such as the South African "biltong", the South American "charque", and the Italian "bresaola" and states that, currently, these salted products or dried meats, made of pieces of pork, beef, goat, venison, and horse, represent a wide variety of products and their characteristic taste is one of the important attributes for consumers.

Like in the rest of the world, salted and dried meat are products widely used in Brazil as a source of animal protein. Salting and drying operations give meat products a distinctive flavor resulting from salt and water removal by drying (Sabadini et al., 2001). These operations are used in the preservation of meat and meat products, especially in some regions such as in many cities in the Northeast of Brazil, where products like sun-dried meat and jerky beef are quite traditional.

Meat blanket can be produced on an industrial scale, requiring the application of modern slaughtering techniques, consistent and systematic hygiene and sanitation procedures, improvement and standardization of manufacturing techniques, and the use of appropriate packaging, which enables obtaining high-quality and high value-added products with favorable and proper marketing conditions. Planning production activities that are aimed at obtaining high-quality products that do not pose health risks to consumers and cause losses to producers can be achieved with the use of Good Manufacturing Practices [GMP] and Hazard Analysis and Critical Control Points [HACCP] systems, in which critical problems are prevented so as to avoid sources of contamination.

Water activity $[\mathrm{Aw}]$ is one of the most important factors for microorganism growth. High water activity values, 0.981.00 , facilitate the development of nearly all microorganisms, in particular bacteria. Levels below 0.87 inhibit the growth of most bacteria and yeasts. The inhibitory action of growth is enhanced by a decrease in the hydrogen potential $[\mathrm{pH}]$ and the addition of sodium chloride to the products (Terra, 2005). Accordingly, Staphylococcus aureus are designated halotolerant bacteria, facultative anaerobic that can produce a very thermostable enterotoxin, which once present in foodstuff are capable of resisting to conventional thermal processing.

Several authors (Sperber, 1983; Leitão, 1988; Bergdoll, 1989) have determined minimum values of water activity ranging from 0.93 and 0.86 to preclude the production of this enterotoxin.

Given the potential of the salted lamb meat blanket of Petrolina and the lack of technical information regarding the product process and quality, this study aimed to describe in detail the process of obtaining salted lamb meat, to identify hazards and control measures in the production stages and evaluate its quality considering the process peculiarities and the product potential for geographical indication.

\section{Materials and methods}

This study was carried out in three Bodódromo restaurants, the gastronomic complex located in the city of Petrolina$\mathrm{PE}$ which prepare special recipes with goat and lamb meat, especially the so-called "barbequed goat", mostly made of salted lamb meat.

The lamb carcasses selected for the production of salted meat blankets were obtained from animals raised in the Lower Basin region of the San Francisco River Valley under production systems that use little chemicals, emphasizing the use of native pastures or adapted to the semi-arid conditions such as prickly pear forage crop, buffel grass pasture, and maniçoba. There is a predominance of sheep of naturalized (Brazil) genetic groups and their crossbreeds of various breeds, such as: Rabo Largo; Bergamácia Brasileira; Morada Nova; and Santa Inês. The animals used to prepare the salted lamb meat blanket were slaughtered at the Municipal Slaughterhouse of Petrolina, which has Municipal Inspection Service [SIM].

An in loco monitoring of the process to prepare the salted lamb meat blanket in the three restaurants was performed, providing the details of the various steps involved, as well as the analysis of potential hazards related to it. The identification of potential biological, physical, and chemical hazards, which could pose risks to consumer's health was performed using the Hazard Analysis System recommended by the World Trade Organization [WTO], the United Nations Food and Agriculture Organization [FAO] and World Health Organization [WHO].

Microbiological analyses were performed on 27 lamb meat blanket samples originated from nine carcasses and processed by three restaurants (processing methods); three carcasses from each restaurant; samples were collected during three different process steps (carcass receipt, post-blanket processing, and postdrying). The three carcasses from each restaurant were marked upon receipt (collection at the $1^{\text {st }}$ site) to follow the process and the next collections (post-blanket processing and post-drying). At each processing site, about $600 \mathrm{~g}$ sample from various parts of the meat blanket were aseptically collected according to method described by ordinance No 101 (Portaria $n^{\circ} 101$ ) (Brasil, 1993), packed in sterile bags, identified, and transported in isothermal boxes to the laboratory for microbiological analyses. The presence of total and thermotolerant coliforms, halophilic bacteria, Salmonella sp, and Staphylococcus aureus was assessed. Microbiological analyses were performed using the methods described by normative instruction $n^{\circ} 62$ (Brasil, 2003) for total and thermotolerant coliforms, Staphylococcus aureus, and Salmonella spp. Halophilic bacterial counts were performed according to ordinance No 101 (Brasil, 1993).

The samples were collected for physicochemical analyses from the drying chamber shortly after the completion of this process. The experiment was conducted with three processes and ten repetitions, and a total of 30 blanket samples were analyzed. Several portions of each blanket were randomly sampled from several muscles, totalizing two kilograms, were packed in polyethylene bags, identified, and transported in cool boxes.

The determination of $\mathrm{pH}$ was performed using a digital $\mathrm{pH}$ meter (Quimis, model Q-400 AS, São Paulo, Brazil), according to 
the official AOAC (Association of Official Analytical Chemistis, 2000) method $n^{\circ} 943.02$. Water activity was determined by the official AOAC (Association of Official Analytical Chemistis, 2000) method $n^{\circ} 978.18$, using a hygrometer (Decagon Devices, AQUALAB model CX-2, Washington, USA). Determination of moisture and chlorides were performed according to the AOAC official methods $n^{\circ} 950.46$ and $n^{\circ} 935.47$ (Association of Official Analytical Chemistis, 2000).

\section{Results and discussion}

It was observed that in general the restaurants follow the production steps of meat blanket production, according to the flowchart shown in Figure 1. After slaughter and the inspection process, the carcasses are transport from slaughterhouse to the restaurants 12 hours after slaughter, on average. The major steps for the preparation of the salted lamb meat blanket are: rawmaterial receipt (substrate), meat blanket processing (boning and manteação- blanket processing), dry salting drying, and packaging.

Upon receipt, the carcasses are checked and weighed, following the meat processing steps. In general, animals whose body weight reaches minimum carcasses weight of $11 \mathrm{~kg}$, with well-built muscles and good fat distribution are preferred.

The carcasses are taken to the processing room, where the process starts immediately after they are collected. There is no air conditioning unit in the room where the carcasses are storage and processed.

Boning and meat blanket processing are essential steps in the salted lamb meat production since they are responsible for the characteristics (deboned meat with specific shape) that define the product, hence the name meat blanket. These steps help salt distribution/penetration, promote drying, and add value to the product since they enable the removal of bones, with little loss of muscle tissue.

This process includes four consecutive procedures:

1 Cleaning: the carcass is initially suspended with the use of hooks in the tarsometatarsal joints with the ventral cavity facing the professional skilled to make the salted lamb meat blanket (operator), who cleans it by removing the pelvic fat and kidney, and then, the tenderloin, which is used for preparing the steak skewer or other culinary preparations in the kitchen of the restaurants.

2 Removal of the backbone: it starts from cutting the sacral bone on both sides following an imaginary line parallel to the column. The cutting of the ribs is also performed on both sides of the carcass at the height of the column insertion, starting from the $13^{\text {th }}$ to the first rib. After cutting the ribs, the muscles are separated inside the carcass.

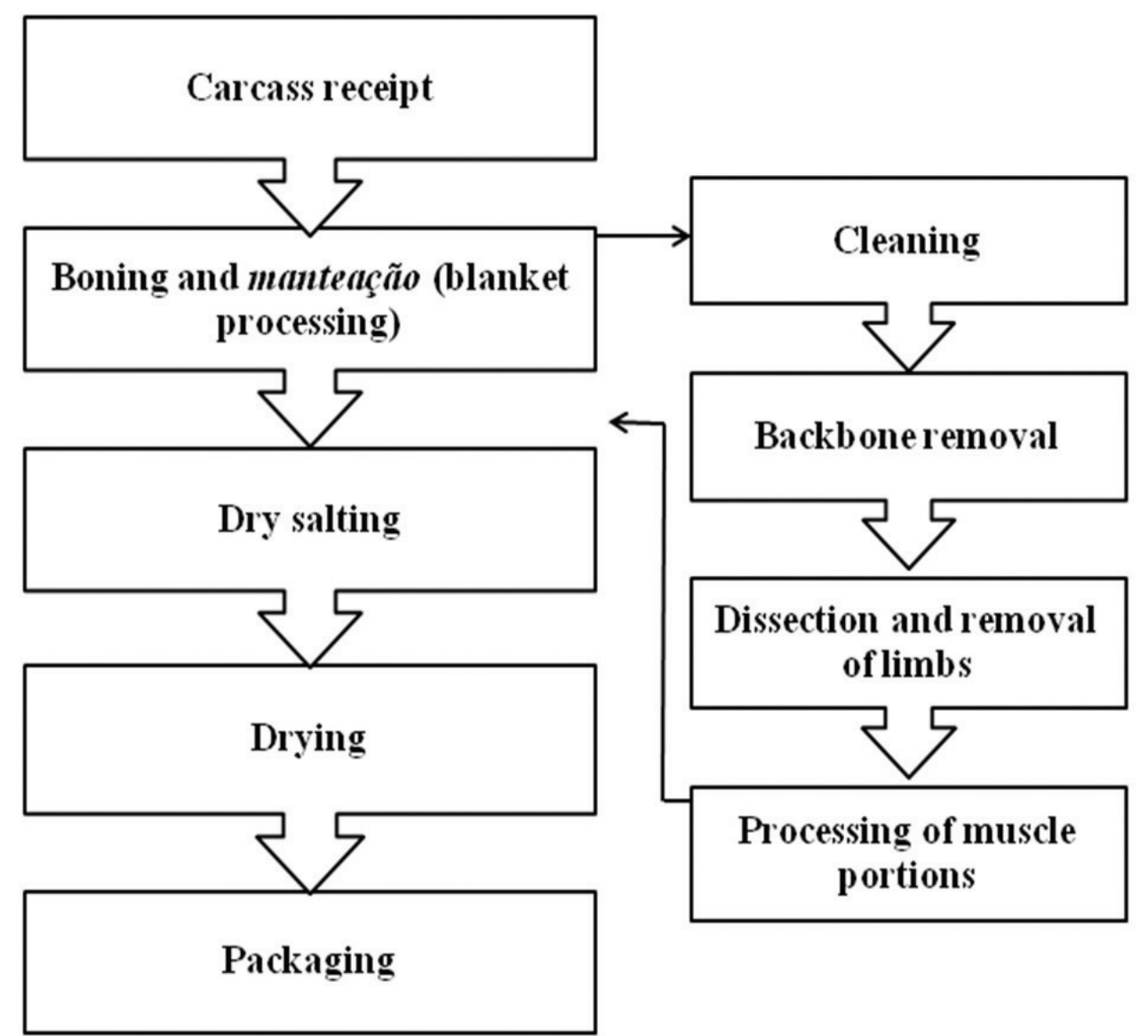

Figure 1. Flowchart for the preparation of salted lamb meat blanket. 
This procedure is accomplished from the insertion of the tail, at the rump region. Thus, the backbone is held in the sacral region and pulled, continuing dissection up to the beginning of the neck, removing the backbone.

3 Dissection and removal of limbs: as part of the deboning, the ribs are separated (including the ribs connected to the sternum in the ventral part) on both sides of the carcass to facilitate meat processing. The meat blanket is then placed on a stainless steel table, and the lymph nodes (glands) is removed, followed by dissection from the inside of the carcass to remove the bones of front and rear limbs. Boning is partial, remaining shoulder blades and ribs, which help support the meat in hooks during drying. The remaining bones are removed and used in culinary preparations such as lamb stew and pirão (manioc flour thickened broth).

4 Manteação of muscular portions: meat blanket process consists of cuts penetrating the muscular portions of the carcass. It is made by observing the following sequence: loin, hindquarter muscle; silverside, roast beef, rump, topside, and knuckle; forequarter; shoulder blade; fore ribs, and striploin. These parts are cut in a way to open the muscles in portions of 1.0 to $2.5 \mathrm{~cm}$ in thickness, varying according to the muscular volume. The reduction of muscle thickness due to processing aims to accelerate salt penetration and moisture reduction, besides being responsible for the characteristics that identify the product.

After the blanket processing, dry salting is performed by simple deposition of cooking salt (sodium chloride) on the entire surface (inner and outer) of the meat cut. The salt is deposited by hand, (250-350 g), always trying to distribute it uniformly according to the carcass size. A standard meat blanket weight/grams of salt ratio has not been established. After salting, the salted side of the meat blanket is folded, weighed, and dried.

For drying, the meat blankets are hung facing down on metal lines inside the drying chamber. Drying is carried out in wind and sun for three to up to 5 hours. This period varies depending on the particular needs of the restaurant and the weather conditions during exposure of the meat blankets. Next, still inside the drying chamber, they are cut into pieces ranging from $7 \times 7 \mathrm{~cm}$ to $11 \times 11 \mathrm{~cm}$, which are packaged in plastic bags properly labeled with information about weight and date of production. The packaged product is then stored in a domestic freezer for 3 to 4 days until use. The product is consumed in the form of barbecue, where the meat shredded in pieces are placed in specific barbecue skewers and grilled in masonry barbecue grills. The skewers are prepared according to the consumption needs of each restaurant, which can be done on the day that the blankets are produced.

The present study and details of the process demonstrated the similarity of production methods adopted among the producers. It was observed that the process involves the use of a traditional technology in the region, which uses salting, ancient preservation method, but with a specific boning technique, peculiar of the region, and manteação (blanket processing) of muscle portions to obtain a characteristic meat product of great exploration potential.

According to Guimarães (2006), differentiated products from goat and lamb breeding obtained with the incorporation of a territorial and cultural identity are an alternative of great potential in the semi-arid region of Brazil. The valorization of local products is, in the context of globalization, a great strategic tool to achieve the main goals of preserving local resources while promoting social equity. The knowledge and recognition of the local "know-how" linked to such products, associating it to the scientific knowledge necessary for its full expression, should be complemented with the implementation of food safety standards that define and guide its quality certificate, which is a basic requirement for its recognition and protection.

Based on the observation of the process to obtain salted lamb meat blanket, the following possible sources of chemical, physical, or biological contamination should be observed: rudimentary slaughtering procedures, poor carcass and meat handling, use of inappropriate or contaminated utensils, and poor hygienic practices of operators. Table 1 shows the main physical, chemical, and biological hazardous agents that may contaminate raw-material and products as well as the probable causes and control measures to prevent these hazards.

The values shown in Table 2 express the microbiological evaluation carried out in strategic stages of the processing of salted lamb meat blanket. All samples showed absence of Salmonella sp and count $<10 \mathrm{MPN} / \mathrm{g}$ of halophilic bacteria.

Staphylococcus aureus counts showed high values for all samples. The results show that throughout the process observed in three restaurants, salted lamb meat blankets were unfit for human consumption, according to RDC $n^{\circ} 12$ (Brasil, 2001) of the National Sanitary Surveillance Agency [ANVISA]. All samples had counts above the permitted value, ranging from of $8.1 \times 10^{3} \mathrm{CFU} / g$ to countless. High contamination by Staphylococcus aureus indicates a possible contamination by operators since this microorganism commonly inhabits human skin and nasopharynx (Murray et al., 2000).

These results show that, according to Brazilian Ordinance (Resolução) RDC no 12 (Brasil, 2001) section “5” - meat and meat products and subsection " $n$ "- salted meat products, which is similar to salted meat blanket, the product tested negative for Salmonella, but it exceeded the limit set for Staphylococcus.

In this subsection, there are no recommended standards for thermotolerant Coliforms.

The counts of Staphylococcus aureus are worthy of note due to the fact that it is a facultatively anaerobic halotolerant bacteria that is able to overcome the obstacles of the Theory of Leistner obstacles (Leistner, 1985) and because it can produce thermostable enterotoxin, which once present in foodstuff, is capable of resisting to conventional thermal processing techniques. According to several authors (Sperber, 1983; Bergdoll, 1989), a minimum value water activity ranging from 0.93 and 0.86 is necessary to preclude the production of this enterotoxin. The Aw $(0.97 \pm 0.02)$ obtained for the product 
Table 1. Hazards and control measures in the process to obtain salted lamb meat blanket.

\begin{tabular}{|c|c|c|c|}
\hline Process steps & Hazards $^{1}$ & Causes & Control measures \\
\hline $\begin{array}{l}\text { Receipt of } \\
\text { carcasses }\end{array}$ & $\begin{array}{c}\text { (B):Pathogenic } \\
\text { Microorganisms (Salmonella, } \\
\text { S. aureus) } \\
\text { (Q): Veterinary drugs } \\
\text { (F): Hair and surface dirt in } \\
\text { the carcass }\end{array}$ & $\begin{array}{l}\text { Poor hygiene conditions in the slaughtering } \\
\text { process and transport; Abuse in storage } \\
\text { temperature and transportation of raw } \\
\text { materials. } \\
\text { Poor veterinary management (lack of respect to } \\
\text { the grace period). } \\
\text { Poor hygiene practices with animals and meat } \\
\text { production (carcass). }\end{array}$ & $\begin{array}{l}\text { Requirement for application of Good } \\
\text { Manufacturing Practices in slaughtering } \\
\text { and transportation processes. Control the } \\
\text { temperature of storage and transportation of } \\
\text { raw materials. } \\
\text { Selection of suppliers. }\end{array}$ \\
\hline Salting & $\begin{array}{c}\text { (B): Pathogenic } \\
\text { Microorganisms (Salmonella, } \\
\text { S. aureus) } \\
\text { (F, Q) Foreign bodies and } \\
\text { impurities. }\end{array}$ & $\begin{array}{l}\text { Too long time and high temperature favor the } \\
\text { growth of pathogens. } \\
\text { Poor sanitary conditions in the work } \\
\text { environment and operators. } \\
\text { Impurities may come from salting operation. }\end{array}$ & $\begin{array}{l}\text { Adequacy of facilities, staff training, time } \\
\text { control of operations, personal, environmental, } \\
\text { and operational hygiene conditions. } \\
\text { Employee training; implementation of GMP. } \\
\text { Purchase of good-quality raw materials. }\end{array}$ \\
\hline Drying & $\begin{array}{l}\text { (B): Pathogenic } \\
\text { Microorganisms (Salmonella, } \\
\text { S. aureus) } \\
\text { (F):Insects, fragments, } \\
\text { foreign bodies. }\end{array}$ & $\begin{array}{l}\text { Poor sanitary conditions in the work } \\
\text { environment and operators. } \\
\text { Inadequate facilities (drying chamber); } \\
\text { operational deficiency. }\end{array}$ & $\begin{array}{l}\text { Staff training. } \\
\text { Maintenance of the chamber (closed and } \\
\text { screened) }\end{array}$ \\
\hline Packaging & $\begin{array}{c}\text { (B): Pathogenic } \\
\text { Microorganisms (Salmonella, } \\
\text { S. aureus) } \\
\text { (Q, F): Foreign bodies or } \\
\text { substances (dirt, insects hair, } \\
\text { chemical substances and } \\
\text { contaminants) }\end{array}$ & $\begin{array}{l}\text { Deficiency in the control of the freezer storage } \\
\text { temperature. } \\
\text { Incorrect storage (bags are open or unfit for } \\
\text { food storage). } \\
\text { Place of storage in poor working condition. }\end{array}$ & $\begin{array}{l}\text { Staff training, cleaning, and freezer } \\
\text { maintenance. } \\
\text { Implementation of good storage practices }\end{array}$ \\
\hline
\end{tabular}

${ }^{1}(\mathrm{~B})$ - Biological hazards; (Q) - Chemical hazards; (F) - Physical hazards.

Table 2. Mean values of microbiological counts and Salmonella in salted lamb meat blanket.

\begin{tabular}{|c|c|c|c|}
\hline \multirow{2}{*}{ Variable } & \multicolumn{3}{|c|}{ Restaurant } \\
\hline & A & B & $\mathrm{C}$ \\
\hline \multicolumn{4}{|l|}{ Receipt } \\
\hline Total coliforms (UFC/g) & $1.7 \times 10^{6}$ & $2.8 \times 10^{5}$ & $5.2 \times 10^{6}$ \\
\hline S. aureus (UFC/g) & $3.1 \times 10^{4}$ & $4.4 \times 10^{4}$ & $5.3 \times 10^{6}$ \\
\hline Salmonella (presence/absence) & Absence & Absence & Absence \\
\hline Total coliforms (UFC/g) & $1.9 \times 10^{4}$ & $6.7 \times 10^{3}$ & $5.4 \times 10^{4}$ \\
\hline Thermotolerant coliforms (UFC/g) & $7.2 \times 10^{3}$ & Absence & Absence \\
\hline S. aureus (UFC/g) & $8.1 \times 10^{3}$ & $1.4 \times 10^{4}$ & $3.7 \times 10^{5}$ \\
\hline Salmonella (presence/absence) & Absence & Absence & Absence \\
\hline Halophilic bacteria (NMP/g) & $<10$ & $<10$ & $<10$ \\
\hline \multicolumn{4}{|l|}{ Post-drying } \\
\hline Salmonella (presence/absence) & Absence & Absence & Absence \\
\hline Halophilic bacteria (NMP/g) & $<10$ & $<10$ & $<10$ \\
\hline
\end{tabular}

$\mathrm{n}=3$ replicates per treatment; Absence of lower case letters in rows indicate no significant difference between treatments at $5 \%$. 
Pedrosa et al.

Table 3. Physicochemical parameters (mean \pm standard deviation) of Salted lamb meat blanket.

\begin{tabular}{cccccc}
\hline \multirow{2}{*}{ Variables } & \multicolumn{3}{c}{ Restaurant } & P & Mean value \\
\cline { 2 - 4 } & A & B & C & 0.010 & $69.86 \pm 2.26$ \\
Moistture (\%) & $71.34^{\mathrm{a}} \pm 1.65$ & $69.87^{\mathrm{ab}} \pm 2.22$ & $68.12^{\mathrm{b}} \pm 1.72$ & 0.453 & $1.93 \pm 0.64$ \\
Chlorides (\%) & $1.72 \pm 0.73$ & $2.05 \pm 0.54$ & $2.02 \pm 0.61$ & 6.345 & $6.22 \pm 0.22$ \\
pH & $6.27 \pm 0.19$ & $6.16 \pm 0.26$ & $6.23 \pm 0.20$ & 0.159 & $0.97 \pm 0.02$ \\
Aw & $0.97 \pm 0.01$ & $0.97 \pm 0.02$ & $0.97 \pm 0.01$ & 0.92 \\
\hline
\end{tabular}

$\mathrm{n}=10$ replicates per treatment; means followed by different superscript lower case letters in rows indicate that there is significant difference between treatments at $5 \%$.

(Table 3) is not a barrier to these microorganisms since it does not reach the limit values.

According to Sabadini et al. (2001), Aw can be correlated with the concentration of the salt added and, therefore, it is useful to control product quality. Therefore, it is necessary to conduct further studies in order to verify whether a reduction of Aw and moisture, and an increase in the salt content would not cause adulteration in the product and / or reduce its acceptance.

Observing the results shown in Table 3, it can be seen that the lamb blanket has high moisture content $(69.86 \mathrm{~g} / 100 \mathrm{~g})$. Restaurant C samples had the lowest average (68.12\%), followed by restaurant B (69.87\%), and restaurant A (71.34\%). Such differences $(\mathrm{P} \leq 0.05)$ in the values detected can be associated to the differences in the materials processed and especially to the differences in the drying times used in the three establishments.

Comparing with the moisture content of lamb meat in natura, as reported by Madruga et al. (2005), which vary between 70.81 and $76.07 \mathrm{~g} / 100 \mathrm{~g}$; it can also be observed that there was no considerable reduction of moisture during the drying process of the blankets.

The average of $\mathrm{pH}$ values of samples of the three establishments were not statistically different $(P \geq 0: 05)$, values between 6.16 and 6.27, with an average of $6.22 \pm 0.22$ (Table 3 ). Low-acid food $(\mathrm{pH}>4.50)$ is more susceptible to microbial growth of pathogenic and deteriorating species (Franco \& Landgraf, 2005). The average values of the samples of restaurants $\mathrm{A}, \mathrm{B}$, and $\mathrm{C}$ were $1.72 \%, 2.5 \%$, and $2.2 \%$ to chlorides, respectively (Table 3 ). These are directly associated to salt, indispensable ingredient for the preparation of the blanket. Although the values found for the samples of the three restaurants did not statistically differ $(P \geq 0.05)$, it is worth mentioning that there is no control during the processes followed: the salt is simply deposited by the shredder; the boned carcass and salt to be used are not weighed, there is no standard value for the weight/grams of salt ratio used. The difficulty in standardizing is one of the challenges for handmade products.

The results elucidate that the blanket is a lightly salted meat product, partially dehydrated and, only semi-preserved by salting.

\section{Conclusion}

There is a similarity in the production methods adopted and in the products obtained, which strengthens the need for process standardization and the creation of a technical regulation of identity and quality of this type of meat product.
The chloride content, values of $\mathrm{pH}$, and water activity of the lamb blanket make it a perishable product that requires other methods of preservation, such as refrigeration and freezing, other than salting and drying to maintain its quality.

It is necessary to weigh the amount of sodium chloride and drying process control aiming at the standardization and a possible reduction in the values of Aw in an attempt to provide a safer product to consumers and a more effective life.

Other studies can be developed to determine the shelf life of the blanket in the storage conditions applied, and in different conditions.

The use of hygienic practices to ensure product safety is necessary, and it requires the implementation and control of Good Manufacturing Practices for quality assurance, even considering the simplicity of the process to obtain the salted lamb meat blanket.

The product notoriety and process peculiarity combined with GMP and the organization of the sector, due to the effort of producers, are important factors in achieving Geographical Indication of the Salted lamb meat blanket of Petrolina - PE.

\section{Acknowledgments}

The authors are grateful to Banco do Nordeste do Brasil (BNB) for the financial support; To INSA and EMBRAPA/ CPATSA for the project partnership; to the owners of the Bodódromo restaurants in Petrolina-PE, who offered their facilities to conduct the tests; and to SENAI Technical School at Petrolina for the partnership in carrying out microbiological analyses.

\section{References}

Association of Official Analytical Chemistis - AOAC. (2000). Official methods of analysis. Washington: AOAC.

Bergdoll, M. S. (1989). Staphylococcus aureus. In M. P. Doyle (Ed.), Foodborne bacterial pathogens (cap. 11, pp. 463-523). New York: Marcel Dekker.

Brasil, Ministério da Agricultura, Pecuária e Abastecimento. (1993). Aprova e oficializa os métodos analíticos para o controle de produtos de origem animal e seus ingredientes: métodos microbiológicos (Portaria n 101, de 11 de Agosto de 1993). Diário Oficial da República Federativa do Brasil.

Brasil, Ministério da Agricultura, Pecuária e Abastecimento. (2003). Oficializa os métodos analíticos oficiais para análises microbiológicas para controle de produtos de origem animal e água (Instrução 
normativa $n^{\circ}$ 62, de 26 de Agosto de 2003). Diário Oficial da República Federativa do Brasil.

Brasil, Ministério da Saúde. (2001). Aprova o regulamento técnico, padrões microbiológicos para alimentos (Resolução RDC n ${ }^{\circ} 12$, de 02 de Janeiro de 2001). Diário Oficial da República Federativa do Brasil.

Costa, R. G., Duarte, T. F., Madruga, M. S., Medeiros, G. R., Pedrosa, N. A., \& Voltolini, T. V. (2010). Manta de Petrolina: uma alternativa para agregar valor às carnes caprina e ovina. Campina Grande: MCT/INSA.

Costa, R. G., Medeiros, G. R., Duarte, T. F., Pedrosa, N. A., Voltolini, T. V., \& Madruga, M. S. (2011). Salted goat and lamb meat: typical regional product of the city of Petrolina, state of Pernambuco. Small Ruminant Research, 98(1), 51-54. http://dx.doi.org/10.1016/j. smallrumres.2011.03.017

Franco, B. G. M., \& Landgraf, M. (2005). Microbiologia dos alimentos. São Paulo: Atheneu.

Guimarães, C. (2006). Situação atual e perspectivas da caprinocultura no Vale do São Francisco. In Anais do $6^{\circ}$ Congresso Nordestino de Produção Animal, Petrolina.

Hierro, E., Hoz, L., \& Ordóñez, J. A. (2003). Headspace volatile compounds from salted and occasionally smoked dried meats (cecinas) as affected by animal species. Food Chemistry, 85(1), 649-657.

Leistner, L. (1985). Hurdle technology applied to meat products of the shelf stable products and intermediate moisture foods types. In J. L. Multon (Ed.), Properties of water in foods (pp. 309-329). Dordrecht: Martinus Niyhoff. http://dx.doi.org/10.1007/978-94-009-5103-7_19
Leitão, M. F. (1988). Microbiologia de alimentos. In I. Roitman, L. R. Travassos \& J. L. Azevedo (Eds.), Tratado de microbiologia (Vol. 1, pp. 3-81). São Paulo: Manole.

Madruga, M. S., \& Bressan, M. C. (2011). Goat meats: descripition, rational use, certification, processing and technological developments. Small Ruminant Research, 98(1), 39-45. ttp://dx.doi. org/10.1016/j.smallrumres.2011.03.015

Madruga, M. S., Sousa, W. H., Rosales, M. D., Cunha, M. G. G., \& Ramos, J. L. F. (2005). Qualidade da carne de cordeiros Santa Inês terminados com diferentes dietas. Revista Brasileira de Zootecnia, 34(1), 309-315. http://dx.doi.org/10.1590/S151635982005000100035

Murray, K., O’Rourke, A. L., McLay, J., \& Simmonds, R. (2000). Use of ground beef model to assess the effect of the lactoperoxidase system on the growth of Escherichia coli O 157: H7, Listeria monocytogenes and Staphylococcus aureus in red meat. International Journal of Food Microbiology, 57(3), 147-158. http://dx.doi.org/10.1016/ S0168-1605(99)00208-1

Sabadini, E., Hubinger, M. D., Sobral, P. J. A., \& Carvalho, B. C. (2001). Alterações da atividade de água e da cor da carne no processo de elaboração da carne salgada desidratada. Ciência e Tecnologia de Alimentos, 21(1), 14-19.

Sperber, W. (1983). Influence of water activity on foodborne bacteria a review. Journal of Food Protection, 46(2), 142-150.

Terra, N. N. (2005). Apontamentos de tecnologia de carnes. São Leopoldo: Unisinos. 